\section{PARASITIC INFECTION OF SOME WILD ANIMALS AT THEKKADY IN KERALA}

\author{
K.R. Easwaran ${ }^{1}$, Reghu Ravindran ${ }^{2}$ and K. Madhavan Pillai ${ }^{3}$ \\ ${ }^{1}$ Assistant Forest Veterinary Officer, Project Tiger, Thekkady, Kerala \\ 685536, India. \\ ${ }^{2}$ Ph.D. Scholar, Division of Parasitology, I.V.R.I., Izatnagar, Bareilly, \\ Uttar Pradesh 243122, India. \\ ${ }^{3}$ Professor of Parasitology (Retd.), Department of Parasitology of \\ Veterinary and Animal Sciences, Mannuthy, Thrissur, Kerala, India.
}

Helminthic infection is wide spread in wild animals and may cause mortality and morbidity of varying degrees. Gour et al. (1979) and Fowler (1986) have stated that the wild animals in the free-living state are generally infected with numerous parasites, but cause little harm to them, unless they are stressed. Therefore, understanding the rate of infection in wild animals is important since infections could result in massive die-offs of wild animals during extreme stress conditions. There are several reports of parasitic infection in zoo animals, but information of the same in free-living wild animals is scanty. This paper reports the parasitic infection in four wild boars, a calf elephant, a sambar deer and a leopard cat which died at Thekkady forest area in Kerala. The parasites collected during postmortem by the first author were preserved in formalin and brought to College of Veterinary and Animal Sciences, Mannuthy. The specimens were washed, dehydrated, cleared in creosote and examined for specific identity.

All the parasites found in wild boars except Gastrodiscoides hominis and Gnathostoma hispidum commonly infect the domestic pig (Soulsby, 1982). Noda (1973) has reported Ascaris suum from Sus scrofa leucomystax while Henry and Conley (1970) recorded Physosephalus sexalatus from European wild hogs. Occurrence of Amblyoma sp. (ticks) in wild boars is recorded by Rajagopalan et al. (1968). Herbivores and rodents are the common intermediate hosts of Lingutula serrata, which in the adult stage occur in carnivores. Available literature did not reveal the occurrence of larvae of this parasite in Sambar. The elephant calf was heavily infected with strongyle worms and maggots of Cobboldia elephantis and is quite likely that its death may be due to this infection. Sundram (1966) has recorded all these parasites from captive elephants. The Leopard Cat was also heavily infected with Echinococcus granulosus causing enteritis which probably could have contributed to its death.
Acknowledgement

The authors are thankful to the Dean, College of Veterinary and Animal Sciences, Mannuthy for the facilities provided for this study.

\section{References}

Fowler, M.E. (1986). Zoo and Wild Animal Medicine. $2^{\text {nd }}$ edition. W.B. Saunders Company, Philadelphia.

Gour, S.N.S., M.S. Sethi, H.C. Thivari and O. Prakash (1979). Prevalence of helminthic parasties in wild and zoo animals in Uttar Pradesh. Indian Journal of Animal Sciences 49: 159-161.

Henry, V.G. and R.H. Conley (1970). Some parasties of wild hogs in southern Appalachians. Journal of Wildlife Management 34: 913-917. Noda, R. (1973). A new species of Metastrongylus from a wild boar with remarks on other species. Bulletin of Agricultural Biology 25: 2129.

Rajagopalan, P.K., A.P. Patil and M.J. Boshell (1968). Ixodid ticks on their mammalian hosts in the Kyasannur forest disease area of Mysore State, India. Indian Journal of Medical Research 56: 510-526. Soulsby, E.J.L. (1982). Helminths, Arthropods and Protozoa of Domesticated Animals. $7^{\text {th }}$ edition. English Language Book Society and Bailliere Tindall, London.

Sundaram, R.K. (1966). Some common elephant parasites. Kerala Veterinary College Magazine 10: 13-21.

Table 1. The parasites identified during the study at Thekkady.

\begin{tabular}{|c|c|c|}
\hline Host & Site of collection & Parasites \\
\hline \multirow{5}{*}{$\begin{array}{l}\text { Indian Wild Boar } \\
\text { (Sus scrofa cristatus) }\end{array}$} & Intestine & Ascaris suum \\
\hline & Intestine & Ascaris suum \\
\hline & Intestine & $\begin{array}{l}\text { Ascaris suum, Gastrodiscoides } \\
\text { hominis }\end{array}$ \\
\hline & Intestine & $\begin{array}{l}\text { Gnathostoma hispidum, } \\
\text { Physosephalus sexalatus }\end{array}$ \\
\hline & Skin & $\begin{array}{l}\text { Amblyoma sp., Haematopinus } \\
\text { suis }\end{array}$ \\
\hline $\begin{array}{l}\text { Sambar } \\
\text { (Cervus unicolor) }\end{array}$ & Surface of liver & Linguatula serrata (larvae) \\
\hline $\begin{array}{l}\text { Elephant calf } \\
\text { (Elephas maximus) }\end{array}$ & Intestine & $\begin{array}{l}\text { Amira pileata, Decrusia } \\
\text { additicta, Murshidia, Quilonia } \\
\text { rennici, and maggots of } \\
\text { Cobboldia elephantis }\end{array}$ \\
\hline $\begin{array}{l}\text { Leopard Cat } \\
\text { (Felis bengalensis) }\end{array}$ & Intestine & $\begin{array}{l}\text { Toxocara canis, Echinococcus } \\
\text { granulosus, Taenia sp. }\end{array}$ \\
\hline
\end{tabular}

